Journal of the British Association for Chinese Studies, Vol. 8 (2), July 2018

ISSN 2048-0601

(C) British Association for Chinese Studies

\title{
Empire and Visual Pleasure: \\ Reinterpreting the Miao Albums of Yunnan and Guizhou
}

Jing Zhu

Science Museum, London

\begin{abstract}
Traditional scholarship has emphasised the intimate link between the Miao album, a genre of illustration to emerge from colonial expansion in southwest China, and political control. Through a careful reading of evidence collected from prefaces, poems, novels, travel accounts and local gazetteers, this paper argues that these albums were also popularised in the marketplace and viewed for pleasure by consumers who included a far wider section of the population than local government officials alone. Divided into three main sections, it firstly brings the pleasure and curiosity dimensions of Miao albums to the fore; it then argues for a diversity of consumers of these albums than has hitherto been acknowledged, and finally, by probing the process of how and by whom Miao albums were produced, it highlights the participation of professional artists and the widespread practice of copying. Through the decentralisation of the political function of Miao albums, this paper offers new ways of viewing Chinese imperial images within the context of popular culture.
\end{abstract}

Keywords: Miao albums, ethnicity, Yunnan, Guizhou, pleasure, imperialism.

One of the more fascinating products of China's colonial expansion into Yunnan and Guizhou in the late-imperial period was the Baimiao tu 百苗圖 (Miao album), a genre of ethnographic illustration depicting the bodies, cultures and environments of various ethnic minorities of the southwest. Symbolising the growing direct bureaucratic regime of the Ming and Qing dynasties (Giersch, 2006: 71-82; Hostetler, 2001; Herman, 2007; Sutton, 2003: 105-152), Miao albums epitomise the intimate correlation between imperial power and visual regimes. Although the genre is known as the Miao album, the subjects of these works were not confined to the group officially recognised today as Miaozu 苗 
族, but included a number of ethnic minorities in Guizhou, Yunnan, Taiwan, Hunan and Hainan (Diamond, 1995: 99-106). Since the nineteenth century, a number of albums have been brought to Europe and North America, valued for their ethnographic information and as part of the preservation impulse that social Darwinism helped to bring about. As a result, Miao albums can be found not only in Chinese collections, but also in the collections of the Wellcome Trust, the Bodleian Library, the Pitt Rivers Museum, the British Library, the Harvard-Yenching Library, and many other Western institutions (Hostetler, 2001: 213-219; Qi, 2012: 195-285).

The majority of Miao albums consist of images depicting the daily activities of non-Han people in groups, with short accompanying texts describing their clothes, customs, locations and dispositions (Teng, 2003: 451). Although many Miao albums make bold claims about their authenticity and the "truth" of the ethnographic information contained therein, they are more properly read as representations of ethnic minorities informed by the mental image of imperial order created by the male Chinese literati elite. Both images and texts in Miao albums betray the influence of Confucian cultural norms pertaining to marriage customs, clothes, body and gender roles. My PhD research, of which the present article forms a part, examines the ways in which the ethnic minorities of the southwest were represented visually and textually, through which it also explores how the Chinese engendered and visualised imperial experiences.

A number of scholars both in China and the West have highlighted the role of Miao albums as symbols of imperial visual regimes of the great Qing, an idea vividly conveyed in Laura Hostetler's (2001) examination of the albums of Guizhou, and Emma Teng's (2004) investigation of images of indigenous peoples in Taiwan. Their analyses are very convincing and significant for our understanding of the Qing colonial enterprise and China's early modernity in a global context. In the same vein, this paper also contextualises Miao albums as products of empire in parallel to their European contemporaries. But when considering the historiography of studying imperial images, Deborah Poole (1997: 17) reminds us that:

In our rush to uncover the complicitous ties among art, 
representation, and power (or, perhaps more appropriately in this case, race and representation) we frequently forget that images are also about the pleasures of looking. Visual images fascinate us. They compel us to look at them, especially when the material they show us is unfamiliar or strange.

Whilst her focus is modern ethnographic photography, Poole's observation is equally applicable to the study of Miao albums, in which issues of pleasure and circulation have been unexplored. Qi Qingfu (2014: 209), for example, argues that Miao albums of the Qing period were exclusively associated with government officials in Guizhou, since ordinary literati and artists could not penetrate into these remote lands. Thus the intimate association of Miao albums with government officials has led to a historiographical focus on Miao albums' political importance as an imperial tool. It is my contention that such interpretations need to be revisited, in order fully to take into account the roles of the literati, pleasure, and the marketplace in the production and consumption of these albums.

Addressing the continued production of Miao albums even after the Qing Empire had started to decline, Hostetler (2002: 187) suggests a functional transformation "from serving a practical purpose related to governance to becoming objects collected and admired in literati circles." The main section of this paper reconsiders how the function of Miao albums could be better interpreted. Existing scholarship has generally neglected to address the pleasure dimension of Miao albums, or placed it as the counterpart of their political importance in a binary relationship of empire and pleasure (Walravens, 2003: 179-193; Tapp, 2003; Rui, 1973). This paper thus proposes a new way of reading Chinese imperial images, by placing them in the context of late-imperial social and cultural histories of visual and material cultures. It emphasises the mutual constitution of imperial regimes and visual pleasures, arguing that the ways in which imperial ideologies are conveyed, cultivated, disseminated and achieved are through the pleasure of looking.

One may also ask why the pleasure function of Miao albums has been so often ignored. Although different in style, both the illustrations of the Shanhai jing 山海經 (Classic of mountains and seas) and Miao albums were 
representations of the "alien", and reflections of an idealised world order in the mind of the Chinese (Dorofeeva-Lichtmann, 2007: 218). However, Miao albums were conceived as images of ethnographic truth, while the Shanhai jing and its various versions in many other works were regarded as fictional and for pleasure. For example, a Ming scholar Hu Yinglin 胡應麟 (1551-1602) described Shanhai jing as "the progenitor of eccentric language" (gu jin yuguai zhi zu 古今語怪之祖); in the Siku quanshu 四庫全書 (Complete collection of four branches of books), Shanhai jing filled the category of fiction, conceived as the most ancient fiction in China (Xu, 2010: 171). The discussion of such illustrations with apocryphal tales and exaggerated imaginations are very easily linked to the domains of consumption of pleasure, contrasting substantially with traditional interpretations of Miao albums.

In her study of the history of anthropology in nineteenth-century Britain, Efram Sera-Shriar (2013: 109-116) has examined the importance of observational practice influenced by anatomy to the conceptualisation of ethnographic truth. In order to understand the omission of the pleasure function in interpretations of Miao albums and the different comments made about Miao albums and the Shanhai jing, it is necessary to consider how Miao albums were authenticated in late-imperial China. Delving into the prefaces of some Miao albums, it is clear that there is indeed a set of strategies and tactics of claiming to represent ethnographic truth. One of the most important is to emphasise the maker's long engagement with the non-Han, direct observation and proper ethics of recording. Although they are narratives that claim authenticity, such ideas of linking field observation with ethnographic truth have arguably remained very powerful, contributing to our ignorance of the pleasure dimension of Miao albums down to the twenty-first century.

The new ways of reading Miao albums discussed here are situated in two contexts pertaining to the study of popular culture: one is the proliferation of popular ethnography in late imperial China and the other is engagement of popular culture in studies of cultural imperialism. For decades, scholars from the disciplines of history, art history, economic history and literature, have shown us the proliferation of the late imperial economy, characterized by the expansion of the education system, the boom in the printing industry, conspicuous consumption and leisure activities (Johnson \& Rawski, 1985; 
Clunas, 1997; Brook, 1998; Hay, 2010). More recently, some scholars have brought the publication and consumption of popular ethnography into this realm of imperial popular culture. In one popular genre of book, riyong leishu 日用類書 (books for daily use), the encyclopaedia of life in the late Ming period, there is a section introducing the land and customs of "the aliens" (Wang, 2003: 404-450). These encyclopaedias include Wuche bajin 五車拔錦 (Brocades in five wagons), Santai wanyong zhengzong 三臺萬用正宗 (Three stages for thousands of true uses), Wanyong zhengzong buqiuren quanbian 萬 用正宗不求人全編 (Complete and authenticated anthology for thousands of uses without bothering other people), Sancai tuhui 三才圖繪 (Illustrations of three powers) and Miaojin wanbao quanshu 妙錦萬寶全書 (Complete books of thousands of great and beautiful treasures), which were poorly printed in studios in Fujian, but reached a wide range of readers. In her monograph, Ming Qing wenxu zhong de xinan xushi 明清文學中的西南敘事 (The southwest in Ming-Qing literary imagination), Hu Xiaozhen 胡曉真 (2017: 53, 234-248) illuminates a growing market for things associated with the "southwest" including the marriage customs of Miao people, and the legends of female government officials in late-imperial literature and printing enterprises. Additionally, He Yuming (2013: 235) reveals that books such as the Yuan-era Luochong lu 裸蟲錄 (Record of naked creatures), which deals with exotic lands and peoples, were widely read during the late-imperial period. My investigation of Miao albums is discussed within this context of popular ethnographic knowledge in late-imperial China.

The question of how imperial ideas were popularised is central to theories of cultural imperialism originating in British imperial history of the nineteenth and early twentieth centuries beginning in the 1980s (Leonardi, 2013: 49-73). For example, the edited anthology, Imperialism and Popular Culture by John McKenzie (1986), remains one of the most important works examining imperialism within popular culture, in which the musical hall, popular art, fiction, and films are addressed. McKenzie clearly points out the "the central role of imperialism must now be noted in all debates about culture, media, and society in the period between the 1870s and the 1940s" (1986: 14). In the same vein, in a recent publication entitled Illustrating Empire: A Visual History of British Imperialism, Ashley Jackson and David Tomkins (2011: 150-173) claim that people in Britain and the dominions regularly encountered vivid 
portrayals of imperial themes, and that imperial images became part of the furniture of British leisure. Although pertaining to a different historical period and geographical area, the influential historiography of examining the popular engagement of imperialism still raises intriguing questions as to the ways in which Chinese imperial ideologies were popularised through visual and material cultures.

Through a careful reading of evidence collected from prefaces of Miao albums, poems, novels, travel accounts and local gazetteers, this paper argues that Miao albums were popularised in the marketplace and viewed for pleasure by consumers beyond local government officials. Divided into three main sections, it first brings to the fore the pleasure and curiosity dimensions of Miao albums; it then argues for a greater diversity of consumers of these albums than has hitherto been acknowledged, and finally, by probing the process of how and by whom Miao albums were produced, it highlights the participation of professional artists and the widespread practice of copying. Through the decentralisation of the political function of Miao albums, this paper offers new ways of viewing Chinese imperial images within the context of popular culture.

\section{Zhengqi Haoyi 爭奇好異 (Competing to be Eccentric and Chasing Exoticism): The Anxiety of Pleasure}

When discussing the practical use of their albums for governing the non-Han, some officials also expressed concerns that others viewed the Miao albums merely for their exoticism. For example, at the end of his preface to Diansheng Yixi Yinan yiren tushuo 滇省迤西迤南夷人圖說 (Illustrations and text relating to the barbarians in Yixi and Yinan of Yunnan), an album dated to 1788 in the collection of the Museum für Völkerkunde zu Leipzig, Germany, He Changgeng 賀長庚, a local government official in eighteenth-century Yunnan, claimed:

予濫竽仕籍，歷管滇之三迤，體訪治夷之情而難易不齊，爰 就耳目所及, 繪以四十四種, 並録其概於端, 非欲爭奇好異, 聊備為治之採訪雲時. 
Following the fashion of official writings, I wrote several pertaining to Yunnan. My experience recounts the extent of the difficulty of ruling ethnic minorities when they are unbalanced. Based on what my eyes and ears could reach, I depicted forty-four ethnic groups, each paired with an annotation at the end. Rather than for the purpose of competing over curiosity and chasing exoticism, your servant prepares this to rule them and to gather news (Nentwig, 2003: 2).

He initially emphasises that the forty-four images were all based on direct observation, the proper ethics of recording and his long engagement with the Non-Han as an imperial officer. He then announces that the album was not produced for zhengqi haoyi, but for providing useful information for the future governance of the non-Han people. This attempt to emphasise the authenticity of his album, also revealed his disdain for those who designed albums for the pursuit of exoticism. It reveals concern that his album might be viewed for fun despite his intention to contribute to the governance of the non-Han subjects. The ways in which the albums were actually read could, of course, differ from how it was thought they should be read. The fact that the author tried to offer guidance on reading his album, to some extent demonstrates the existence of albums made to convey a sense of exoticism.

Another intriguing dialogue in the preface of Qiannan miaoman tushuo 黔南 苗蠻圖说 (Album of the Miao in southern Guizhou) (1890) by Gui Fu 桂馥, a nineteenth-century government official who worked in Guizhou for more than fifteen years, offers further evidence for the albums' pleasure dimension. The dialogue starts with the mocking of a guest:

客見而誚之: “子真好事業, 前重畫養蒙圖說, 取蒙以養正之 意,又畫訓女圖說，取家人利女貞之意，是皆有補於世. 今 畫苗蠻圖, 於世無補, 只可供人玩好而已, 奚足取? ”

My guest saw [the Miaoman illustrations I made] and mocked: "you are really meddlesome. Previously you re-drew illustrations of raising children, which might be attributed to 
the purpose of educating children with correct methodology; you then depicted illustrations of girls' admonition, and you might do that for women's chastity in a family. All of these are for the benefits of society. Now you painted the illustrations of Miaoman, which will not benefit our society and can offer people only fun and entertainment. Is there any benefit in so doing?" (Li, 2008: 151).

余曰: “唯唯否否, 子不聞古之學者, 為學有要, 置圖於左, 置 書於右, 索象於圖, 索理於書. 秦漢以前, 圖籍散佚, 傳於今 者, 如唐顔師古之王會圖, 宋鄭俠之流民圖, 盛度之西域圖, 元趙孟俯之圈風圖，明楊東民之饑民圖，彭韶之鹽場圖，又 如我朝之職貢圖, 耕織圖, 棉花圖, 皆邀宸翰褒題, 無非取索 象於圖之意. 且黔省自入版圖以來, 苗巒屡滋事矣, 泣茲土 者，苟不悉其風俗，好尚而欲思患，預防不亦難乎? 此余之 畫苗蠻圖, 所亟亟也."

I replied: "With respect, I must disagree. Have you not heard that when scholars of ancient times carried out research they placed illustrations on the left and text on the right, deriving a representation from the illustration and an explanation from the text? Before the Qin and Han dynasties, books were lost. In terms of those that are extant today, such as Yan Gushi's Illustrations of the King's Assembly in the Tang dynasty, Illustrations of Refugees and Shen Du's Illustrations of the Western Areas in the Song dynasty, Zhao Mengfu's Illustrations of Customs of the Bin in the Yuan dynasty, Yang Dongming's Illustrations of Starving People and Pengshao's Illustrations of Salt Making in the Ming dynasty, and Illustrations of Tributaries, Illustrations of Farming and Weaving, and Illustrations of Cotton in our dynasty, all were inscribed by emperors and represented their phenomena through images. Moreover, after Guizhou province was integrated into the territory, Miao barbarians caused trouble frequently. If officials ruling this area are not familiar with the local customs, will it not be difficult to prevent this? That is 
the urgent purpose behind my making of the illustrations of the Miaoman (Li, 2008: 151).

By highlighting a contradiction between Gui Fu's expectations and the guest's actual viewing experience, this dialogue is indeed important, offering new insights into the Miao album's functions. Gui's guest observes the fashion of making illustrations for texts. He argued that while it made sense to him to make illustrations for a son and daughter's education, it was useless to make illustrations of "barbarians", as the phrases yushi wubu 於世無補 (bring no benefits to the society), and zhike gongren wanhao eryi 只可供人玩好而已 (can offer people only fun and entertainment) vividly indicate. Gui then justifies the significance by linking to the theory of suoxiang yutu, suoli yushu 索象於圖, 索理於書 (seeing through images and enlightening through written words), which values images as an essential technique for learning, a methodology initially described by Zheng Qiao 郑樵 (1104-1162), a wellknown Song scholar (Bray, 2007: 1). At the end of the conversation, Gui also explains the instrumental role of the Miao album in ruling the non-Han in Guizhou. Obviously, Gui disagreed with his guest who asserted that the Miao albums could only serve for fun and entertainment.

This was not necessarily a conversation that had actually happened, as other writings also start with the conventional ke yue 客曰 (the guest asks), and yu yue 余曰 (I replied), such as Banqiao zaji 板橋雜記 (Jottings in Banqiao) by Yu Huai 余懷 (1616-1696) (Yu, 2016: 1). Instead, it was a technique employed by the author to convey his themes, purposes and the main concerns of the writing. What was Gui Fu's purpose in listing this dialogue with his guest at the very start of his preface for the album? He might have been concerned that others would see the album in the same way as his guest. He was certainly dissatisfied with the idea that the Miao album was merely for fun and pleasure, and his reply highlights the more "noble" or "exalted" function of the album as an imperial tool.

Gui does not provide any background information about his guest, but this dialogue suggests that Miao albums could be viewed by a much wider range of people. Like Gui's guest, others might have viewed these albums for pleasure and thought that this was their only function; indeed, this may have been the 
perspective of many non-official viewers. The function of Miao albums varied among different consumers in different contexts, but one cannot deny the albums' dimension of fun and their pleasure function.

The pleasure dimension of Miao albums was also best demonstrated through the popularisation of scenes pertaining to gender and sexuality. When opening a Miao album from Guizhou, the second entry is often an image of a nüguan 女官 (female government official) (see fig. 2). This follows an image of the male Hei Lolo 黑羅羅 (Black Lolo, now officially recognised as Yi in the PRC) (Harrell, 2001). This nüguan was the principle wife of the Luoluo ruler and, when her husband died, became a female ruler. The Ming court fully recognised the legitimacy of confirming women as hereditary native chieftains (Gong, 1985: 263-302; Hu, 1981: 242-243). The stories of some female government officials, such as She Xiang 奢香 (1358-1396) and Qin Liangyu 秦 良玉 (1574-1648), became extremely popular and were adapted for drama and fiction (Hu, 2017: 219-250). It is, however, crucial to note that the Qing emperor Yongzheng (r. 1723-35) abolished the native chieftainships and extended direct bureaucratic control over the formerly autonomous frontier areas (Herman, 2007: 47-50). While there were relatively few female government officials after the middle of the eighteenth century, Han literati still displayed a deep fascination with the female local chieftains. Rather than reality, the images of female government officials in Miao albums were the stuff of male Han Chinese imagination; rather than retaining political importance, the images of nüguan here reflect a pleasure dimension to the texts.

Furthermore, a number of scenes in Miao albums depict scenes of ethnic minorities dancing, and these were intimately associated with their marriage custom, tiaoyue 跳月 (dancing under the moonlight). For example, in figure 1, a group of Hua (Flower) Miao are depicted. Men dance and play flutes and women play bells; they are chasing one another, too. The paired text tells the reader that this is a customary way of selecting partners and that the dance is generally followed by sexual intercourse in the open. There are other images showing more intimate scenes between non-Han men and women. The popularity of these scenes relating to marriage customs and sexuality are other indicators of pleasure-seeking. Scholarship addressing such exoticising and eroticizing ethnic others, focussing either on European examples or ethnic 
minorities in modern China, has already developed a rich field of enquiry (Burton, 2016: 495-510; Aldrich, 2013: 74-99; Gladney, 1994: 92-123; Schien, 2000: 1-17; Hyde, 2001: 333-348; Mathieu, 1999: 81-105). One chapter of my $\mathrm{PhD}$ thesis explores Chinese ways of eroticising ethnic minorities in the southwest of China by linking these to sexual regulation, in particular that applied to widows and virgins in the late imperial period (Zhu, 2018: 86-154). Imperial visual order was achieved through the manipulation of sexuality; meanwhile, these gendered and sexual elements in the Miao albums also served, through providing visual pleasure, to promote their circulation among multiple readerships.

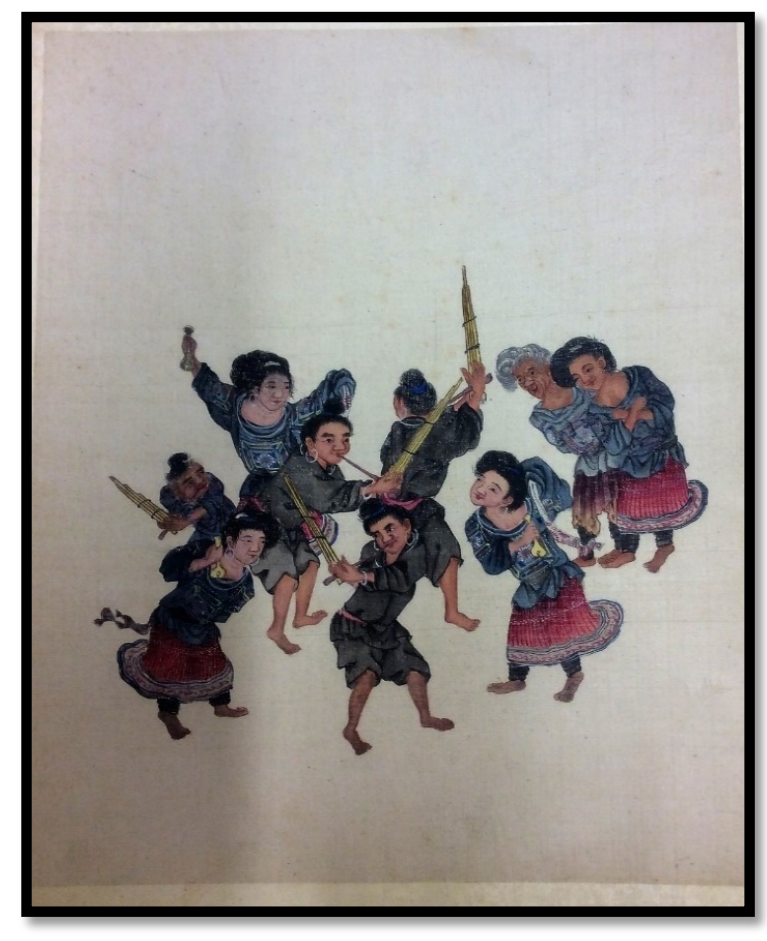

Figure 1. “Huamiao 花苗,” in an untitled album, undated, Wellcome Trust Library, London.

Although the two accounts from $\mathrm{He}$ and Gui discussed above spend much ink addressing the practical utility of Miao albums as tools of imperial colonisation and governance, it is important to note that the production of 
albums was not carried out under the emperor's direction. Instead, it was a fashion that many government officials followed in their spare time. The account in the preface of a 1743 Taiwanese album, Taihai caifeng tu 臺海采風 圖 (Ethnographic illustration in Taihai) demonstrates this point well, as Liu Shiqi 六十七, a Manchu government official in the eighteenth century puts it: 乾隆癸亥冬, 余奉天子命, 來巡斯土 .... 林林總總, 莫不蒸然 向化, 仰見聖治昭宣,無遠不屆. 小臣不才，惟有勤宣朝廷愛 養德意，夙夜不敢自遑，閑及采方問俗，物產之異，種種怪 特，多中土未見者. 始信區宇之廣，其間何所不有. 公余之 㗇，即其見聞可據者，今繪諸冊若幹幅，雖不能殫其十之二 三，而物土之宜，風俗之殊，亦足以表聲教之訖，獻雉貢獒， 無煩重譯也. 爱題臺海采風圖, 彝諸行筴, 歸質於博雅君子.

In the winter of the kuihai year of the reign of Emperor Qianlong (1743), I came to investigate this land with the order of the emperor. ... all are willing to be civilised, waiting to be called and ruled, even for those inhabited far away. I am a minor official, with no talent, and all I could do was to work hard on promoting the intentions of the court which were to raise men of virtue, and I did not dare to relax day or night. When I was free, I interviewed the locals and asked for their customs, including the local exotic products, especially those that could not be seen in the mainland of China. I started to believe that in this grand universe, anything could exist. In the free time when I had accomplished my official duties, I depicted several images based on trustworthy sources. Although it could not even reflect two or three tenths of Taiwan, the nice land and exotic customs are enough to convey the purpose to educate. The scenes of offering the tribute of birds and dogs need no repetition. I named this album Taihai caifeng tu, leaving it in my travelling box, in order to broaden and refine the knowledge of gentlemen (Qi, 2012: 289).

Although this is an album depicting the ethnic minorities in Taiwan, it is still helpful for understanding the production of ethnographic illustrations of late 
imperial China in general, as Taiwan was also part of the Qing colonial enterprise (Teng, 2004). Despite Liu's Manchu background, the text above clearly suggests an imperial tributary system, an imagined and idealised Chinese world order (Perdue, 2015: 1002-1014). Liu's claims that the indigenous Taiwanese were all eager to be cultivated and assimilated by an advanced culture vividly demonstrates imperial or Confucian ideology as adopted by the Manchus for use in certain contexts.

Liu also claims that he had made the album in his spare time, as the words xian 閑 and xia 暇 clearly indicate. Qi Qingfu (2012: 288-290) briefly mentions this text, in his critique of Hostetler's interpretation of the transformation of the Miao albums' functions from imperial tools of officials in the High Qing to objects adored by the literati in the late Qing period, since this is a text written in the High Qing, while revealing less concern with imperial governance. At the end, he clearly states that his purpose is to boya junzi 博雅君子 (broaden and refine the knowledge of gentlemen), an idea probably generated from an earlier book, Bowu zhi 博物誌 (A treatise on broad learnings of things) by Zhang Hua 張華 (232-300), in which the exotic lands, products, and "alien" peoples were introduced (Zhang, 1985: 42-81). The full text tries to shed light on or even exaggerate exotic customs and local products unique to Taiwan. Thus the Miao albums' political use should not be overstated.

Drawing on the above texts by $\mathrm{He}$, $\mathrm{Li}$ and Liu, this paper further demonstrates that the Miao albums are best interpreted by recognising that their functions as an imperial tool and their existence as a material cultural object created for the pleasure of looking are not mutually exclusive. Imperial ideologies and a message of cultural superiority over the non-Han were often most successfully conveyed through the curiosity, surprise and joy provoked by the depiction of exotic and eroticised customs, including scenes illustrating the marriage customs of dancing in the moonlight, and the depiction of naked women bathing (Mann, 2011: 169-185). The image of Shui Baiyi 水摆夷, known as the Dai in contemporary China, were often depicted in scenes of women with naked bodies bathing in a river in the Miao albums of Yunnan, such as Yunnan sanyi baiman tu quanbu 雲南三迤百蠻圖全部 (Complete illustration of all barbarians of three frontiers in Yunnan) in the Bodleain Library. Local government officials' concerns about ruling non-Han peoples and 
about Miao rebellions all suggest an intimate correlation between the Miao albums and the imperial regime in the borderlands. The symbolic meanings of Miao albums have been well demonstrated by such rhetoric, but the extent to which these albums could in practice help local officials to rule the non-Han needs further investigation. In his study of the images of ethnic minorities in Yunnan gazetteers, Giersch (2006: 82) argues that "As with Euro-Americans who formulated Indian policy, the images of indigenous mattered because they shaped Qing assumptions about 'what they thought they could get' from 'barbarians.' In general, Qing officials thought they could get more from those groups who conformed more closely to civilized ideals; these were the groups whom imperial officials sought to cultivate as allies."

Some Miao albums, for example Yunnan yingzhi miaoman tuce 雲南營制苗 蠻圖冊 (Album of Miao barbarians for military use in Yunnan; undated, circa nineteenth century) now in the collection of the Wellcome Trust, also records the Miao rebellions, whether they paid taxes, and what tribute they could offer, which might have been useful for future rulers. To some extent, the barbarians could also help the Han and others feel more "civilised", thereby justifying the mission. However, concerns that the albums might be misunderstood as mere exotic curiosities, and Gui's guest's comment that these illustrations "can offer people only fun and entertainment" suggest that Miao albums also fulfilled other functions. A new way of reading Chinese imperial images is to emphasise both their political importance and the visual curiosity that they provoked, and neither of these aspects should be ignored.

It was not only in imperialism that pleasure was often ignored, but also in the study of art, as Jonathan Hay (2010: 15) observes: "Pleasure, as I have slowly come to understand, is another blind spot in this case of modern art history's system of knowledge. Only by bracketing pleasure can art history inscribe art within the network of binaries-subject-object, centre-periphery, genuine-fake, among others - that continue to define the modern discipline. It is impossible to account for the role of pleasure in art without undoing these binaries, so it is entirely logical that pleasure should become a subject itself at a moment when the epistemology of art history as a discipline is, finally, being radically reconsidered." Thus, it is important to inscribe pleasure in the study of the history of art objects and I have highlighted how looking for pleasure was 
transpired and constructed in Miao albums. This argument can be further strengthened by demonstrating that these albums had viewers besides government officials, as we will see below.

\section{Multiple Viewers: The Growing Market for Popular Ethnography}

By making, collecting or simply viewing an album, the government officials of Yunnan could potentially use them in the governance of the non-Han. However, this section of the article demonstrates that the Miao albums were viewed by those who were not government officials; in fact, they reached a wider range of viewers than has traditionally been assumed. There are more than one hundred Miao albums in museum and library collections world-wide. The argument that Miao albums were exclusively associated with government officials needs to be reconsidered, as it is mainly drawn from those albums with a preface written by such officials. This seems problematic, not least because the majority of albums were anonymous. This section thus reconsiders the readership of the Miao album. They were circulated in several cities outside of Yunnan and Guizhou, including Beijing, Shanxi, Henan and Anhui (Hostetler, 2001: 192). At a time of growing immigration and economic cultivation (Lee, 2000; Lee, 1982: 279-304), the Miao albums are best understood within a context of dynamic and frequent encounters between the Han Chinese and borderland peoples, as well as the growing market for popular ethnography in the form of local gazetteers, travel accounts, fictions, poems and art.

Among the ethnographic writings of the southwest, a genre of poems, recording and commenting on the custom of non-Han, zhuzhi ci 竹枝詞 (Bamboo branch poems), were extremely popular (Zhou, 2012: 1-2). As well as images and textual annotation, poems were included in some Miao albums such as those in the album published by Laura Hostetler and David Deal (2006). Several poems were written after viewing Miao albums. For example, a poem written by Yu Shangsi 余上泪, a local of Guizhou, who was successful in the imperial examination at the provincial level, commented on the images of female government officials: 


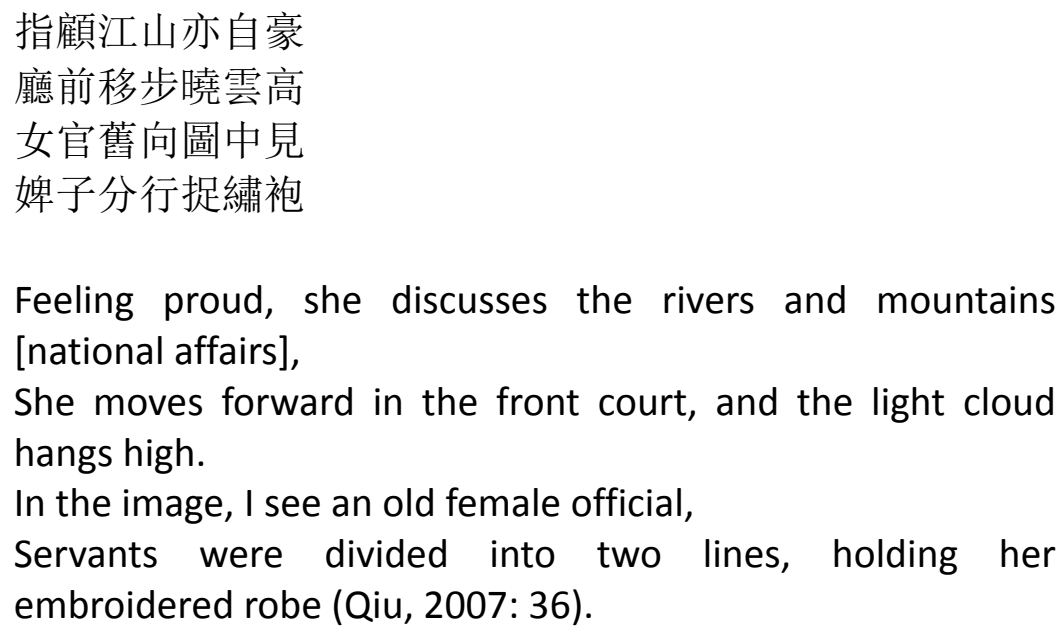

The third line of the poem demonstrates that Yu wrote it after viewing the images of Nüguan. In figure 2, an image of Nüguan in the British Library's collection depicts a female official in an exquisite pleated dress standing in the court and surrounded by servants, resembling the scenes described in Yu's poem. Yu, therefore, probably viewed an album similar to this one. A large number of bamboo branch poems have been written and lower-status literati contributed to this genre. Given the many bamboo branch poems that have been produced and their relationships with Miao albums, it seems that the Miao albums were viewed by literati of different levels. 


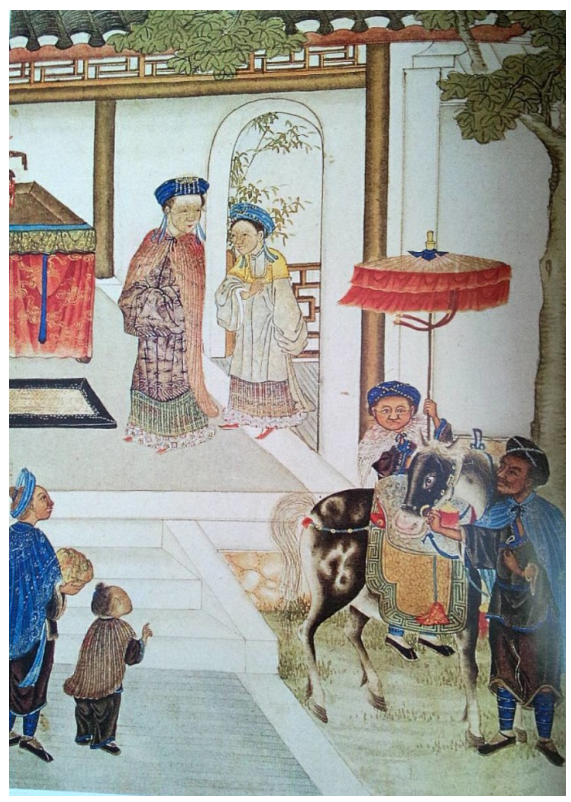

Figure 2. Anonymous, nüguan 女官 (Female Official) in the album Luodian yifeng 羅甸遺風 (Legacies of customs in Luodian), Approximately $18^{\text {th }}-19^{\text {th }}$ century. Album leaf (1 of 20), British Library, London, Series 16594.

A much earlier record in Han shu 漢書 (Book of Han), may also tell us more about the audience and function of ethnographic illustrations in general:

(建昭) 四年春正月，以誅郅支單於告祠郊廟，赦天下. 群臣 上壽置酒, 以其圖書示後宮貴人.

In the first month of spring in the fourth year [of the Jianzhao Reign: $35 \mathrm{BCE}$ ], because the execution of Zhizhi Chanyu [the Xiongnu monarch] was reported in the ancestral temple in the suburbs, there was an amnesty for "all-under-heaven". The ministers wished the emperor longevity with wine, and therefore showed the nobles of the rear palace [i.e., the concubines] illustrations of (the Xiongnu) (Ban, 2007: 74).

Clearly this Illustration of the Huns (an ethnic group in northern China) was shown to the concubines in the imperial palace, rather than the 
traditionally-assumed viewers: emperors. Thus these concubines, who did not participate directly in political administration, might have read the illustrations of the Huns for fun and from a sense of curiosity about an exotic land, people and customs. Women were also an audience for Chinese paintings and illustrations (Clunas, 2017: 87). Although this illustration is rather early, it still helps us to understand the broad audience and functions of ethnographic illustrations, and this piece of text from the Han shu suggests one more potential audience for ethnographic illustrations.

Moreover, the printing of the aforementioned Qiannan Miaoman tushuo, suggests that it was, at least to some extent, intended to be made available to broad audiences, despite only one copy surviving. Several historians of print in late imperial China, including Robert Hegel (1988: 152-157), Joseph McDermott (2006), and Timothy Brook (1998: 112-142) have examined the technical innovation, refinement and standardization of woodblock printing, the rapid growth of audiences and the expansion of popular and vernacular publications. Wood-block prints for illustration printing were widely circulated in the art market during the Ming and Qing dynasties (Clunas, 1997: 134-148). Nianhua (illustrations for the new year) even reached peasants in the villages (Flath, 2004).

Although Qiannan Miaoman tushuo is the only copy extant, the form of print was designed for a broad market. As Gui Fu had successfully published several books about children's education, he was probably also aware of the market for Miao albums. As already mentioned, in her study of the literature pertaining to the southwest, Hu Xiaozhen (2017) has observed the popularization of ethnography in late imperial novels, including Yesou puyan 野舅曝言 (A country codger's words of exposure), Yin shi 蟫史 (History of insects) and Guwang yan 姑妄言 (Arrogant words). For example, in Guwang yan, the author Cao Qujing 曹去晶 observes:

童自宏在貴州雲南住了年余回來, 果然紀了一冊手抄, 名為 峒溪備錄。遂命匠人刻了絕精的版刷印，傳到各書坊中都 有. 腹中稍有文墨者無不喜閱.

Tong Zihong stayed in Guizhou and Yunnan for more than one 
year, and copied a manuscript, titled Tongxi beilu. Then he asked the artists to carve an extremely exquisite printing board. It is available in all bookshops. Even those with only the merest hint of culture in their bellies do not fail to enjoy them (Cao, 1997: 482).

The last sentence in particular indicates the popularity of the ethnographic writings of the southwest. In his study of the sources of the novel, Chen Yiyuan (1997: 129-136) observes that they were largely taken from Dongxi xianzhi 峒 溪纖誌 (Detailed records of Dongxi), a book about the customs and products of the ethnic minorities in the southwest written by Lu Ciyun 陸次雲, an eighteenth-century literati and official. Their production and reproduction in the form of travel accounts, novels and ethnography, has illuminated the consumption of popular ethnography in late imperial China. As mentioned in the introduction, the "alien" was discussed in the late-Ming encyclopaedia of daily lives. This was a genre of relatively poorly printed illustrated books from the studios of Fujian, and was available to a wide range of readers (Wang, 2003: 404-450; Xu, 2010: 169-192). I have argued here that Miao albums were also a genre of ethnographic illustration, and were part of the constellation of popular ethnography produced in various formats in late imperial China.

Several scholars of cultural imperialism have linked popular engagement with empire to the entertainment of the working-class men and women in metropolitan cities in the late nineteenth and early twentieth centuries (Beaven, 2012: 179-207). One frequently cited example is the rise of museums in Britain, an important space for exhibiting the colony and disseminating imperial ideologies among the bourgeoisie, ranging from professionals to a wealthy upper middle class (Mackenzie, 2009; Coombes, 1994). Miao albums, along with other popular ethnography, resemble such European cultural imperialism in several ways, including their association with urban cultures and their wider influences on different levels of readership.

\section{Making Ethnographic Truth? The Paradox of Copying and Participation of} Artists in the Marketplace 
At the very start of this paper, I made the claim that Miao albums were conceptualised and authenticated as products representing ethnographic truth through a set of narrative techniques. In this section, I argue that not all of the albums were made by those who had actually observed the nonHan in their native land; many artists contributed to the genre and copying was pervasive. Norma Diamond (1995) discusses Miao albums in her study of the changing meanings of "Miao" from imperial to contemporary China. She questions "whether most of the artists had ever travelled extensively through the Yunnan and Guizhou frontier areas, let alone spent any time in the Miao communities. At best they may have seen some of these peoples in towns, markets, or along the roads and then, relying on available text and/or access to other "Miao albums," let their imaginations take over to highlight a special marker discussed in the text" (1995: 101). In what follows I seek to prove Diamond's hypothesis that several producers of Miao albums had not actually travelled extensively in the ethnic minorities' homelands, and that many of the Miao albums were made by copying.

Returning to the aforementioned preface of the Qiannan miaoman tushuo, the dialogue between Gui Fu and his guest continues:

客又曰, 若然市中畫工已先為之,何庸再事?

My guest asked again: "professional painters in the market have already done this. Is there any need to repeat their work? (Li, 2008: 151)?

余曰彼畫工家，考核不精，所作倮苗仡仲各種服飾，大概相 同, 其膚色皆隨意而施, 所畫率本黔人張某所作八十二種苗 蠻詩記. 其中有仲混為苗者, 有苗混為僚者, 有一種二名而 分畫者, 甚至如古州地方苗仲徭僮難處，大寨稱爺頭，小寨 名洞崽, 竟以爺頭, 洞崽偽為二種, 所住地方, 亦多錯叱. 余 今所畫, 大都親眼所及, 非畫工家所可同語.

I replied: Those painters in the marketplace, their examination (of ethnic minorities) is not quite precise. The costumes of Luo, Miao, Ge, and Zhong are almost the same; the skin colours are applied freely; [I guess] what they depict 
follows the Eighty-two Miao Barbarian Poems and Accounts, by someone called Zhang. Some of them mix Zhong with Miao, Miao with Liao; those who are the same kind, but have two names are depicted twice. For example, in Guzhou where Miao, Zhong, Yao and Zhuang rebelled, people in the large stockaded village, are called Yetou, while they are called Dongzai in the small stockaded village. However, these painters wrongly consider Yetou and Dongzhai to be two different categories. In terms of the places they inhabit, most of them are recorded incorrectly. What I have painted here is based on my direct observations. Those made by professional painters cannot compare with mine (Li, 2008: 151).

The question posed by the guest reveals that some Miao albums were actually made by professional painters, indicating that some albums were produced for the market and were available to a wide range of consumers. In response, Gui admitted that Miao albums circulated in the market place and that most were based on an album by "Zhang mou" 张某 (a certain Mr Zhang), a local of Guizhou. The omission of Mr. Zhang's full name might suggest that he was of lower status, probably a professional artist or one of the literati of lower classes of Guizhou.

Gui also emphasises the roughness and inaccuracy of Miao albums made by professional artists, and highlights the accuracy of his own album, which he claims is based on meticulous observation. Gui obviously wanted his albums to stand out in the marketplace, but his comments also confirm for us that many Miao albums were copied.

Miao albums also attracted the interest of European and American missionaries, diplomats, art dealers, adventurers and anthropologists who visited China in the late nineteenth and early twentieth centuries, and several of them were collected and brought back to Europe and America. Archibald Colquhoun recorded a conversation about Miao albums that he had with a school-master in Yunnan in his well-known travel account, Across Chrysê: Being the Narrative of a Journey of Exploration through the South China Border Lands from Canton to Mandalay published in 1883: 
He [the school master] pointed out to us several of the different tribes present, and did us a great service, through the tin-chai, by telling him of the existence of a series of pictures of the aboriginal people, made by an amateur artist (a gentleman who painted for pleasure). This man, he said, was dead, but copies, he believed, were extant in Kaihua. One series had been sent to the Viceroy of Yunnan as a present, and one was in the possession of his family, at Kaihua (Colquhoun, 1883: 359-360).

This text indicates that this particular Yunnan album was made by a gentleman who painted for pleasure, something which supports the argument above about the pleasure dimension of Miao albums. It also demonstrates those participating in the albums' production extended beyond the official class. Moreover, the confidence of the school-master about the existence of copies in Kaihua again provides evidence that many albums were copied. The school-master also said that one series had been sent to the Viceroy of Yunnan as a present, which suggests another possible source for the albums in the government officials' collections.

The way in which the Bolin tushuo 伯麟圖說 (Illustration and texts of Bolin) was made provides further evidence that copying was common. The Bolin tushuo was an album of Yunnan commissioned by the Manchu governor Bolin 伯麟 (?-1823) in 1818, which was given significant attention in Daoguang Yunnan tongzhi gao 道光雲南通誌稿 (Draft of gazetteer of Yunnan during the Daoguang reign). An album with twenty-two entries entitled Yunnan zhongren tushuo 雲南種人圖說 (Illustration and texts for the ethnic groups in Yunnan), in the collection of the library of Yunnan University, is said to have been selected from Bolin tushuo (Yunnan University Library, 2005: 6-7). Bolin appointed Li Gu 李沽, a renowned local artist of Yunnan in the nineteenth century, to make an album for him. Based on Li's collection of Yunnan zhuyi tu 雲南諸夷圖 (Illustrations of barbarians in Yunnan), Li remade an album for the governor, which became the Boling tushuo (Yunnan University Library, 2005: 6). This seems to suggest that it was common to make albums by copying, especially among the artists who were commissioned to make albums, or who made an 
album for the marketplace. Although several officials, like Gui Fu, professed to despise professional artists because they copied Mr. Zhang's album, in reality, even government-commissioned albums such as the Bolin tushuo were copied.

Some scholars have suggested that the Yunnan sanyi baimantu 雲南三迤百 蠻圖, an album in the collection of Chinese Academy of Social Sciences, is a copy of Bolin tushuo (Qi: 2012: 59-67). Among the extant Miao albums, I have found that both Yunnan sanyi baiman tu quanbu 雲南三迤百蠻圖全部 (Complete illustration of all barbarians of three frontiers in Yunnan) in the Bodleian library, Oxford, and Yiren tushuo mulu 夷人圖說目錄 (Catalogue of illustrations and texts of the barbarians) in the Harvard-Yenching Library are similar albums to the Yunnan sanyi baimantu. Moreover, Qi (2014: 70-92) has found five more similar albums in the collection of Chinese libraries and museums. These various copies of the same original strongly indicate the prevalence of copying in the production of Miao albums. Furthermore, it was the pleasure dimension of Miao albums and the demand of non-official viewers that stimulated this copying.

Although it is another genre, a consideration of the Zhigong tu 職貢圖 (Tributary illustrations), which depicts foreigners on their way to or at the Chinese court to offer gifts, such as jewellery, and fortune animals, to the Chinese emperor, and showing their respect and willingness to be "civilised" (Lai, 2012: 1-72), is a potentially useful avenue for understanding the production of ethnographic illustrations more broadly. Peng Nian's 彭年 (15051566) colophon to the Tributary Illustrations, attributed to Qiu Ying 仇英 (1494-1552), records that:

此卷畫於懷雲陳君家, 陳君名官, 長洲人, 與十洲善, 館之山 亭, 屢易寒暑, 不相促迫, 由是獲畫. 其心匠之巧, 精妙麗密, 各極意態, 雖人殊國異, 而考按圖誌, 略無違謬. 能事直出古 人上.

This handscroll was painted at the house of Mr. Chen, who is called Huaiyun. Mr. Chen's given name is Guan, and he is 
from Changzhou. He hosted [Qiu] at his mountain pavilion repeatedly for several winters and summers. There [Qiu] was not hurried or forced; hence, he was able to make complete use of the skill of his mind's inventions, which were refined, subtle, and beautiful, with fully conceived ideas. Although the men of the different nations are foreign, they have been examined according to the [various] nations' records, and in the end nothing is disregarded or in error. In his ability he has surpassed the men of antiquity (Chang, 2004: 7).

This text indicates that Qiu's Tributary Illustrations was influenced by his frequent viewings of the paintings of his friend Mr. Chen. Though Qiu has been honoured as one of the Four Great Masters of painting of the Ming Dynasty, very little is known about his life. His name, unlike the other three Great Masters of Ming Painting, Shen Zhou (1427-1509), Wen Zhengming (14701559), and Tang Yin (1470-1523), did not appear in the social writings of his contemporaries because he was a professional painter and therefore considered a member of the artisans, while the other three artists were literati, in the upper level of the social strata (Laing, 1999: 69-89). Thus this scroll attributed to Qiu suggests the engagement of professional painters with ethnographic illustrations.

China has a long history of depicting and recording the customs of foreigners and domestic ethnic others, and it has generally been assumed that the makers of ethnographic illustrations were court painters who had the opportunity to observe foreigners coming to the Chinese court, the diplomats who were sent to investigate the borderlands and the local government officials ruling the local ethnic minorities as suggested in the prefaces of several tributary illustrations (Wang, 2014: 190-195). Yet the involvement of Qiu, a professional painter, in the production of tributary illustrations, at least indicates the popularity of the genre. As one product in the proliferating late imperial art market, the symbolic and ideal imperial blueprint was thus popularised and circulated among officials, literati and even the semi-literate. The title of the scroll, Tributary Illustrations, clearly suggests an idealised world order in Ming imagination; the scroll of Qiu thus offered another wonderful example of the juxtaposition of empire, commercialisation, and pleasure. 
The discovery of the prevalence of copying complicates our understanding of how ethnographic knowledge was produced. In his examination of the sources representing the “alien", Ge Zhaoguang 葛兆光 observes the intermingling of previous ethnographies, whether travel accounts, imaginative tales or more "reliable" new ethnographies based on direct observations in late-imperial China (Ge, 2004: 347-370). Although Luochong lu has traditionally been assumed to be entirely fictional because of its many references from Shanhai jing, He Yuming (2013: 227-230) has emphasised its relevance to diplomacy during the Ming dynasty. Earlier, I noted that the Shanghai jing and Miao albums have traditionally been viewed very differently: one as fiction; the other as reality. Thus one has to be cautious when linking the fictional illustrations with popular culture, while associating those based on direct observations with "truth", since the lines between imagination and reality, copy and new product were often blurred.

Other intriguing issues are to what extent albums with a preface claiming their authenticity, such as the aforementioned Diansheng Yixi Yinan yiren tushuo and Qiannan miaoman tushuo, differed from commercial Miao albums. And which, if any, Miao albums housed in the various modern libraries and museums are copies of Mr. Zhang's work made by professional painters, as mentioned by Gui Fu and his guest? Comparing albums with prefaces claiming their authenticity with anonymous albums reveals that the composition and the content of the albums, and the scenes selected for representation are all quite similar. For example, figure 3 , an image from an unsigned and unprefaced album depicting eighty-two ethnic groups, Qiansheng miaotu, in the collection of the Pitt Rivers Museum, depicts a group of Miao in a picnic scene. On the left, an old man in a blue robe is lying over the arm of a young Miao woman feeding him alcohol with a horn cup. The other three figures on the right all look towards the drinking couple.

The group of black Miao in figure 4, taken from Qinannan miaoman tushuo, is similar to the Miao in figure 3. Although the artist added pines trees to the mountain, the main part of the image still depicts a group of Miao sitting around some bowls of food. A Miao woman feeds an old Miao man and all the other figures laugh at them. Gui Fu has even enlarged the horn cup held by the 
lady standing at the right, which highlights their exotic material culture; the later image divided the figures into three groups and each group contains a male and a female, which further appeals to the viewers' sexual imaginations. These themes were what a good Confucian order was trying to get rid of, and were set as the opposite side of late imperial sexual regulations in the Chinese upper class. The information expressed through these images pertaining to gender and sexuality were quite rich, and one of the functions was to convey the "uncivilized" status of the ethnic minorities in the periphery, which constituted part of the visual order of the empire.

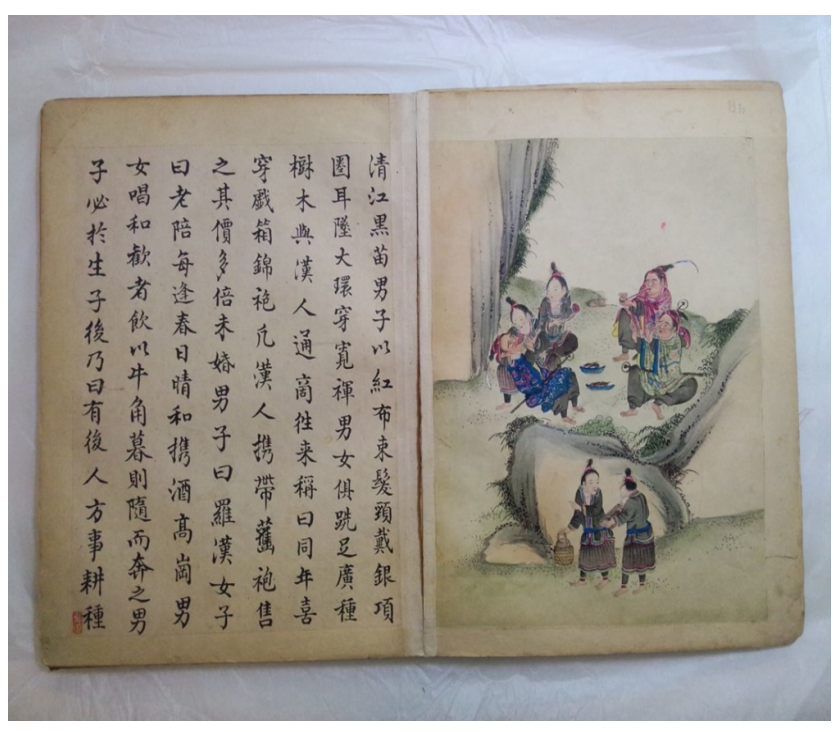

Figure 3. Anonymous, "Qingjiang Heimiao 清江黑苗 (Black Miao in Qingjiang)" in an album of Qiansheng miaotu 黔省苗圖 (Miao album of Guizhou), undated (approximately 18th or 19th century), Pitt Rivers Museum, Oxford, no. 1917.53.723. 


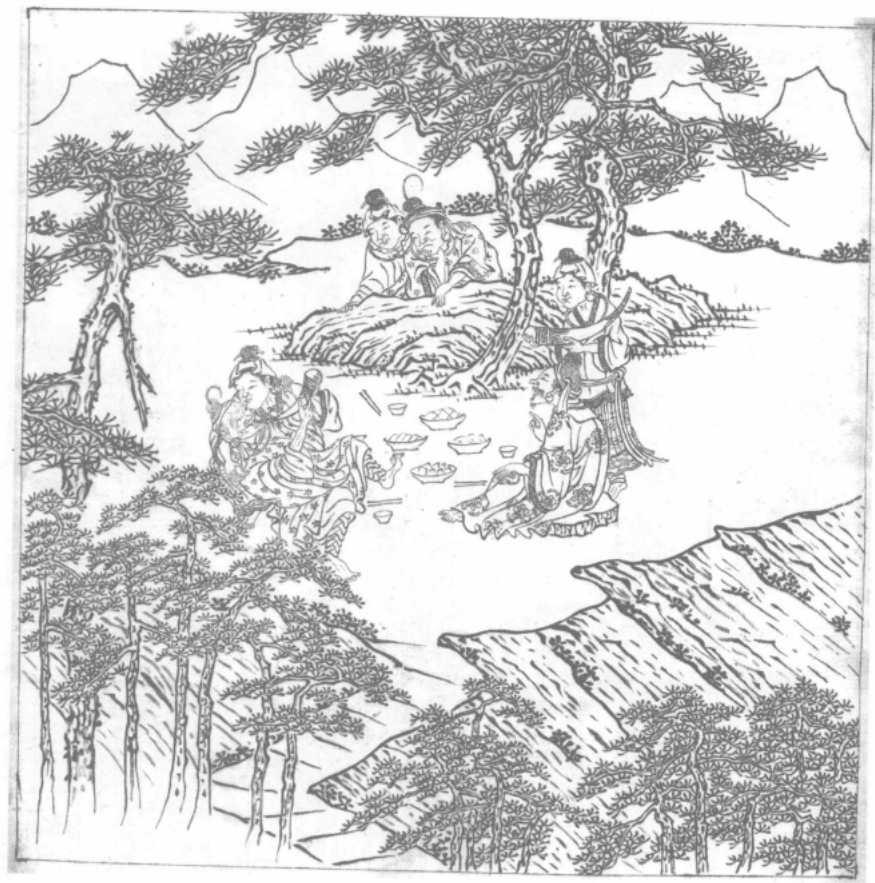

Figure 4. Gui Fu, “Qingjiang Heimiao 清江黑苗 (Black Miao in Qingjiang),” in an album of Qiannan miaoman tushuo 黔南苗蠻圖說 (Images and text on Miao barbarians in southern Guizhou), $19^{\text {th }}$ century, Ancient book collection of Zhongyang Minzu Daxue, Beijing.

The contents and composition of the images in Gui Fu's Miao album undermines his claims in the album's preface about its authenticity. This also complicates our understanding of the relationship between words and images (Mitchell, 1980: 3). The Miao albums indicate that images can tell a different story to that conveyed by words, and this paper has demonstrated the high value of images for historical analysis, a discipline traditionally dominated by text (Burke, 2001). Furthermore, among several studies of the representation of ethnic minorities in tourism, dances and heritage parks in modern China, Louisa Schien (2000), Jing Li (2013: 69-100), and Stevan Harrell (2013: 285-297) stress the commercialisation of the culture of ethnic minorities, and perhaps a modern day version of the pleasure seeking we see in imperial China. 


\section{Concluding Remarks}

By both zooming in and zooming out of the Miao albums, this paper enlarges upon previous understandings of these works. Bringing the pleasure dimension to the fore and examining makers, consumers, and production processes in light of recent scholarship, has allowed this paper to pose some basic questions about the use and circulation of Miao albums and their pleasurable use that have never been fully addressed. Although this paper departs, at times, from Hostetler's interpretations of the function of Miao albums, its overall placement of China as an empire in parallel to its European contemporaries is broadly in accord with her conclusions, highlighting the popularisation of China's imperial imagery. Following Teng's underlining of the need to explore imperialism from cultural angles (2004: 12), this paper links the production of Miao albums to late imperial popular culture.

Apart from government officials, professional artists also participated actively in the making of Miao albums, and the practice of copying was widespread. There was a rhetorical hierarchy of expectations about how Miao albums should be viewed-some government officials wished only to communicate the value of ruling the non-Han, and did not want their Miao albums to be viewed for enjoyment. Yet, as this article has indicated, in practice the albums might be viewed in ways that their creators would not admit to facilitating. Some viewers, in particular the non-official class, may have only read the Miao albums for pleasure, but this did not weaken their role as imperial images, since the ways in which visual pleasure was achieved was often bound up with imperial orders related to gender, morality, rites and sexual regulations.

In his influential and powerful work, Steven Shapin (1995) has reflected on the ways in which trust, truth and moral order were constructed in seventeenth-century England, and this paper has sought to bring similar reflections to the production of ethnographic knowledge in late imperial China. The omission of the pleasure dimension of the Miao albums in existing historiography is indicative of the way in which ethnographic truth and imperial regimes in late imperial China have been conceptualised. The 
narrative of ethnographic truth is set in a binary relationship with the pleasure of looking. Disdaining the pursuit of the curious and the exotic was a powerful way in which some producers claimed the authenticity of their Miao albums.

As was suggested by Jonathan Hay, "pleasure should become a subject itself" (2010: 15), and this article seeks a reinterpretation of Chinese imperial images by taking pleasure seriously, by penetrating the ways through which ethnographic knowledge was generated, by decentralising the political function of the Miao albums, and by complicating the binary relationship between imperial tools and pleasure. Although some albums emphasize their political value for ruling the non-Han, they still manifest great fascination with images, like female government officials in Guizhou, moon dance scenes, nonHan women bathing in rivers and Miao women in short skirts. Imperial superiority was conveyed through these images pertaining to gender and sexuality; meanwhile these elements popularized the production and circulation of ethnographic images. Imperial vision and pleasure were, in fact, mutually constituted and reinforced. By shining a spotlight on the proliferation of popular ethnography, and emphasising the importance of copying, this paper has sought to resituate Miao albums within late imperial Chinese social and cultural history. Such a reinterpretation might also prove fruitful with regards to other imperial images in China, including the tributary illustrations, as well as modern ethnographic photography produced in republican China and in the PRC.

Inspired by studies of imperial engagement of popular culture in the domain of leisure and recreation, a discipline mainly generated from European, in particular British examples, this paper has revealed that Chinese imperial images shared several similarities with their European counterparts in terms of their popularity, commercialisation and the engagement of growing urban audiences. Yet, as several scholars remind us, it is not easy to generalise from imperial theories, which are often based on textual analysis from different historical epochs and geographic locations (Wilcox, 2016: 18; Levine, 2007: 113). Bearing this in mind, this specific research into the consumption, production, and proliferation of Miao albums helps us to understand the nexus between politics and popular entertainment, amateur and professional artists, copying and direct observation, truth and imagination, and empire and 
visual pleasure in the ongoing creation and definition of empire in late imperial China.

\section{References}

Aldrich, Robert (2013), "Sex Matters: Sexuality and the Writing of Colonial History", 74-99, in Andrew Thompson (ed.), Writing Imperial Histories, Manchester: Manchester University Press.

Ban Gu (2007), Han shu (Book of Han), Beijing: Zhonghua shuju.

Beaven, Brad (2012), Visions of Empire: Patriotism, Popular Culture and the City, 1870-1939, Manchester: Manchester University Press.

Bray, Francesca (2007), "Introduction: The Powers of TU", 1-78, in Francesca Bray, Vera Dorofeeva-lichtmann and Georges Metailie (eds.), Graphics and Text in the Production of Technical Knowledge in China: The Warp and the Weft, Leiden and Boston: Brill.

Brook, Timothy (1998), The Confusions of Pleasure: Commerce and Culture in Ming China, Berkeley: University of California Press.

Burke, Peter (2001), Eyewitnessing: The Uses of Images as Historical Evidence, London: Reaktion Books.

Burton, Jonathan (2016) "Bodies, Sex and Race: Western Encounters with Sex and Bodies in Non-European Cultures 1500-1750", 495-510, in Sarah Toulalan and Kate Fisher (eds.), The Routledge History of Sex and the Body 1500 to the Present, Abingdon, Oxon: Routledge.

Cao, Qujing (1997), Guwangyan (Arrogant words), Taipei: Taiwan Daying Baike Gongsi.

Chang, Su-Chen (2004), "A Flourishing Scene of Prosperity: A Study of the Scroll 'Qingming Shanghe Tu' Attributed to Qiu Ying”, unpublished PhD thesis, University of Oregon.

Chen, Yiyuan (1997), "Guwangyan sucai laiyuan erkao" (Second research on the sources of Guwangyan), Mingqing xiaoshuo yanjiu 4: 127-136.

Clunas, Craig (1997) Pictures and Visuality in Early Modern China, London: Reaktion Books.

- - (2017), Chinese Painting and its Audiences, Princeton: Princeton University Press.

Colquhoun, Archibald (1883), Across Chrysê: Being the Narrative of a Journey 
of Exploration Through the South China Border Lands from Canton to Mandalay, London: Low, Marston, Searle and Rivington.

Coombes, Annie (1994), Reinventing Africa: Museums, Material Culture and Popular Imagination in Late-Victorian and Edwardian England, New Haven, CT: Yale University Press.

Diamond, Norma (1995), "Defining the Miao: Ming, Qing, and Contemporary Views", 92-116, in Stevan Harrell (ed.), Cultural Encounters in China's Ethnic Frontiers, Seattle: University of Washington Press.

Dorofeeva-Lichtmann, Vera (2007), "Mapless Mapping: Did the Maps of Shan haijing Ever Exist?", 217-294, in Francesca Bray, Vera DorofeevaLichtmann and George Métailié (eds.), Graphics and Text in the Production of Technical Knowledge in China, Leiden: Brill.

Flath, James (2004), The Cult of Happiness: Nianhua, Art, and History in Rural North China, Seattle: University of Washington Press.

Ge, Zhaoguang (2004), "Shanhai jing, zhigong tu he luxingji zhong de yiyujiyiLima Dou laihua qianhou zhongguoren guanyu yiyu de zhishi ziyuan jiqi bianhua" (The memory of foreign land in classics of mountains and seas, tributary illustrations and travel accounts-the sources and its transformation pertaining the alien by Chinese before and after the visit of Matteo Ricci), 345-369, in Zhong Caijun and Yang Jinlong (eds.), Mingqing wenxue yu sixiang zhong zhi zhuti yishi yu shehui, Taipei: Zhongyanyuan wenzhesuo.

Giersch, Patterson (2006), Asian Borderlands: The Transformation of Qing China's Yunnan Frontier, Cambridge, MA: Harvard University Press.

Gladney, Dru (1994), "Representing Nationality in China: Refiguring Majority/Minority Identities", The Journal of Asian Studies 53: 92-123.

Gong, Yin (1985), Mingqing Yunnan tusi tongzuan (An edited compilation of native chieftains in Yunnan during the Ming and Qing dynasties), Kunming: Yunnan minzu chubanshe.

Hay, Jonathan (2010), Sensuous Surfaces: The Decorative Object in Early Modern China, London: Reaktion Books.

Harrell, Stevan (2001), Perspectives on the Yi of Southwest China, Berkeley, Calif.; London: University of California Press.

- - (2013), "China's Tangled Web of Heritage", 285-297, in Tami Blumenfield and Helaine Silverman (eds.), Cultural Heritage Politics in China, New York: Springer. 
He, Yuming (2013), Home and the World: Editing the "Glorious Ming" in Woodblock-printed Books of the Sixteenth and Seventeenth Centuries, Cambridge, Massachusetts: The Harvard University Asia Center.

Hegel, Robert (1988), Reading Illustrated Fiction in Late Imperial China, Stanford: Stanford University Press.

Herman, John (2006), “The Cant of Conquest: Tusi Offices and China's Political Incorporation of the Southwest Frontier", 135-170, in Pamela Crossley, Helen Siu and Donald Sutton (eds.), Empire at the Margins: Culture, Ethnicity, and Frontier in Early Modern China, Berkeley: University of California Press.

- - (2007), Amid the Clouds and Mist: China's Colonization of Guizhou, 12001700, London: Harvard University Asia Center.

Hostetler, Laura (2001), Qing Colonial Enterprise: Ethnography and Cartography in Early Modern China, Chicago: The University of Chicago Press.

Hostetler, Laura and David Deal (2006), The Art of Ethnography: A Chinese "Miao Albums", Seattle: University of Washington Press.

$\mathrm{Hu}$, Qingjun (1981), Mingqing Yizu shehuishi luncong (Collected essays on the history of Yi society during the Ming and Qing dynasties), Shanghai: Shanghai renmin chubanshe.

$\mathrm{Hu}$, Xiaozhen (2017), Mingqing wenxue zhongde xinan xushi (The southwest in Ming-Qing literary imagination), Taipei: Taida chuban zhongxin chuban.

Hyde, Sandra (2001), "Sex Tourism Practices on the Periphery: Eroticizing Ethnicity and Pathologizing Sex on the Lancang in China Urban: Ethnographies of Contemporary Culture", 333-348, in Nancy Chen (ed.), China Urban: Ethnographies of Contemporary Culture, London: Duke University Press.

Jackson, Ashley and David Tomkins (2011), Illustrating Empire: A Visual History of British Imperialism, Oxford: Bodleian Library.

Johnson, David \& Rawski, Evelyn (1985), Popular Culture in Late Imperial China, Berkeley: University of California Press.

Lai, Yuzhi (2012), "Tuxiang diguo: Qianlong chao zhigongtu de zhizuo yu didu chengxian" (Picturing empire: illustrations of "official tribute" at the Qianlong court and the making of the imperial capital), Bulletin of the Institute of Modern History, Academia Sinica 75: 1-76.

Laing, Ellen (1999), "Problems in Reconstructing the Life of Qiu Ying", Ars 
Orientalis 29: 69-89.

Leonardi, Cherry (2013), "The Power of Culture and the Cultures of Power: John MacKenzie and the Study of Imperialism", 49-73, in Andrew S. Thompson (ed.), Writing Imperial Histories, Manchester: Manchester University Press.

Library of Yunnan University (ed.) (2005), Qingdai dianqian minzu tupu (Ethnographic illustrations of Yunnan and Guizhou in Qing dynasty), Kunming: Yunnan meishu chubanshe.

Lee, James (2000), The Political Economy of a Frontier: Southwest China, 12501850, Cambridge, MA: Harvard University Press.

- - (1982), "The Legacy of Immigration to Southwest China, 1250-1850", Annales de Demographie Historique, 279-304.

Levine, Philippa (2007), Gender and Empire, Oxford: Oxford University Press.

$\mathrm{Li}$, Delong (2008), Qiannan miaoman tushuo yanjiu (Research on the Miao barbarian in southern Guizhou], Beijing: Zhongyang minzu daxue chubanshe.

Li, Jing (2013), "The Making of Ethnic Yunnan on the National Mall: Minority Folksong and Dance Performances, Provincial Identity, and 'The Artifying of Politics' (Zhengzhi yishuhua)", Modern China 39(1): 69-100.

Lu, Ciyun (1968), Dongxi xianzhi (Detail accounts of Dongxi), Guangwen shuju.

MacKenzie, John (ed.) (1986), Imperialism and Popular Culture, Manchester: Manchester University Press.

- - (2009), Museums and Empire: Natural History, Human Cultures and Colonial Identities, Manchester: Manchester University Press.

Mann, Susan (2011), Gender and Sexuality in Modern Chinese History, Cambridge: Cambridge University Press.

Mathieu, Christine (1999), "History and Other Metaphors in Chinese-Mosuo Relations Since 1956", 81-105, in Antonia Finnane and Anne McLaren (eds.), Dress, Sex and Text in Chinese Culture, Clayton, Vic.: Monash Asia Institute.

McDermott, Joseph (2006), A Social History of the Chinese Book: Books and Literati Culture in Late Imperial China, Hong Kong: Hong Kong University Press.

Mitchell, W. J. T. (1980), "Introduction: The Language of Images", 1-8, in W. J. T. Mitchell (ed.), The Language of Images, Chicago, IL: University of Chicago Press. 
Mitchell, William (ed.) (1980), The Language of Images, Chicago: The University of Chicago Press.

Nentwig, Ingo (2003), Das Yunnan-Album Diansheng Yixi Yinan Yiren Tushuo. Illustrierte Beschreibung der Yi-Stämme im Westen und Süden der Provinz Dian, Leipzig: Museum für Völkerkunde zu Leipzig.

Perdue, Peter (2015), "The Tenacious Tributary System", Journal of Contemporary China 24: 1002-1014.

Poole, Deborah (1997), Vision, Race, and Modernity: a Visual Economy of the Andean Image World, Princeton, N.J.: Princeton University Press.

Qi, Qingfu (ed.) (2012), Qingdai shaoshu minzu tuce yanjiu (Research on ethnographic illustrations in Qing dynasty), Beijing: Zhongyang minzu daxue chubanshe.

- - (2014), Minzu wenhua zazu (Anthology of nation and culture), Beijing: Zhongyang minzu daxue chubanshe.

Qiu, Renliang et al. (eds.) (2007), Zhonghua zhuzhici quanbian (Complete bamboo branch poem in China), vol. 7, Beijing: Beijing chubanshe.

Rui, Yifu (ed.) (1973), Miaomantuji (A collection of album of Miao and barbarian), Taipei: Zhongyang yanjiuyuan lishiyuyan yanjiusuo.

Schien, Louisa (2000), Minority Rules: The Miao and the Feminine in China's Cultural Politics, Durham: Duke University Press.

Sera-Shriar, Efram (2013), The Making of British Anthropology, 1813-1871, London: Pickering \& Chatto.

Shapin, Steven (1994), A Social History of Truth: Civility and Science in Seventeenth-century England, Chicago: University of Chicago Press.

Sutton, Donald (2003), “Ethnic Revolt in the Qing Empire: The 'Miao Uprising' of 1795-1797 Reexamined', Asia Major 16(2): 105-152.

Tapp, Nicholas and Don Cohn (2003), Tribal Peoples of Southwest China, Bangkok: White Lotus.

Teng, Emma (2003), "Texts on the Right and Pictures on the Left: Reading the Qing Record of Frontier Taiwan", 451-487, in Judith Zeitlin Liu and Ellen Widmer (eds.), Writing and Materiality in China: Essays in Honor of Patrick Hanan, London: Harvard University Press.

- - (2004), Taiwan's Imagined Geography: Chinese Colonial Travel Writing and Pictures, 1683-1895, Cambridge, MA: Harvard University Asia Center.

Thompson, Andrew (2013), Writing Imperial Histories, Manchester: Manchester University. 
Waley-Cohen, Joanna (2004), "The New Qing History", Radical History Review 88: 193-206.

Walravens, Hartmut (2003), "Illustrations of Ethnic Groups in Southwestern China", 179-193, in Allan Nigel (ed.), Pearls of the Orient: Asian Treasures from the Wellcome Library, London: Serindia Pub.

Wang, Yong (2014), "Shanhai jing tu yu zhigong tu" (Illustrations of classics of mountains and seas and tributary illustrations), 190-195, in Zhao Zhongya (ed.), Wangyong wencun, Nanjing: Jiangsu renmin chubanshe.

Wang Zhenghua (2003), "Shenghuo zhishi yu wenhua shangping: Wan Ming Fujianban riyong leishu yuqi shuhuamen" (Life, knowledge and cultural commodities: the books for daily use in Fujian studios in late Ming and the section on paintings and calligraphy], Zhongyang yanjiuyuan jindaishi yanjiusuo jikan 41: 1-85.

Wilcox, Emily (2016), "Beyond Internal Orientalism: Dance and Nationality Discourse in the Early People's Republic of China, 1949-1954", The Journal of Asian Studies 3(16): 1-24.

Xu Huilin (2010), “Chaogong de xiangxiang: wan Ming riyongleishu 'zhuyi men' de yiyulunshu" (Tributary imagination: the narrative of "section of the alien" in books for daily use in late Ming), Zhongguo wenzhe yanjiu tongxun 20(2): 169-92.

Yu, Huai (2016), Banqiao zaji (Jottings in Banqiao), Zhengzhou: Zhengzhou guji chubanshe.

Zhang, Hua (1985), Bowu zhi (A treatise on broad learnings of things), Beijing: Zhonghua shuju.

Zhou, Jianjun (2012), "Minzu wenxue shiye xia de zhuzhici yanjiu” (Research on bamboo branch poem in the context of ethnographic literature), unpublished PhD thesis, Zhongyang minzu daxue.

Zhu, Jing (2018), "Visualising Ethnicity in the Southwest Borderlands: Gender and Representation in Late Imperial and Republican China," unpublished PhD thesis, University of Edinburgh.

Jing Zhu is a UK-China Rutherford Research Fellow at the Science Museum in London. 
36 Jing Zhu 